\title{
BIBLIOTECA DR. UROS BACIC
}

Fue expresa voluntad del Dr. Uros Bacic legar su biblioteca particular a la biblioteca del Departamento de Economía, brindando así su último aporte a nuestra universidad. Lamentablemente, el aceleramiento de su enfermedad le impidió concretar personalmente la donación. Poco después de su muerte, la familia materializó su deseo legándonos tan valioso material.

Indudablemente, la biblioteca del Departamento de Economía se ve beneficiada con este aumento importante en su acervo de libros, revistas y archivos, cuya calidad constituye la más acabada muestra de la talla académica del Dr. Uros Bacic. Se alternan publicaciones de autores clásicos y modernos en idioma español, inglés, francés, alemán e italiano de una vasta temática en la que predominan obras de microeconomía, teoría de la ciencia, sistemas económicos, economía de la eduación y economía regional.

La donación fue aceptada por el Consejo Departamental del Departamento de Economía por resolución CDE 0203/92 del 24 de diciembre de 1992.

Todo el material donado ha sido incorporado como "Biblioteca Dr. Uros Bacic". con una referencia de clasificación bibliográfica que la identifica particularmente, habiéndosele destinando además un lugar especial en el ámbito de la Biblioteca del Departamento de Economía. 